\title{
Karyomorphology and Its Evolution in Dipterocarpaceae (Malvales)
}

\author{
Kazuo Oginuma ${ }^{1 *}$, Shawn Y. K. Lum² and Hiroshi Tobe ${ }^{3}$ \\ ${ }^{1}$ The Community Center for the Advancement of Education and Research at the University of Kochi, \\ 5-15 Eikokuji-cho, Kochi 780-8515, Japan \\ ${ }^{2}$ Asian School of the Environment, Nanyang Technological University, Singapore 639798 \\ ${ }^{3}$ Department of Botany, Graduate School of Science, Kyoto University, Kyoto 606-8502, Japan
}

Received January 16, 2020; accepted February 9, 2020

\begin{abstract}
Summary Previous chromosome information is restricted to Dipterocarpoideae, one of the two subfamilies of Dipterocarpaceae, and no chromosome information is available for another subfamily Monotoideae. Here we present the first karyomorphology of Marquesia macroura $(2 n=22)$ (Monotoideae), as well as of four species $(2 n=22)$ of four genera in tribe Dipterocarpeae and five species $(2 n=14)$ of tribe Shoreae in Dipterocarpoideae. Comparisons within Dipterocarpaceae and with Sarcolaenaceae $(2 n=22)$ sister to Dipetrocarpaceae in the light of phylogenetic relationships show that the basic chromosome number $x=11$ is plesiomorphic and $x=7$ apomorphic in Dipterocapaceae. Based on available information, tribe Shoreae $(x=7)$ has a uniform karyotype where all chromosomes have a centromere at median position, while the rest of the family $(x=11)$ have a diverse karyotype in terms of the frequency of chromosomes with a centromere at median, submedian and subterminal position. We discussed the meaning of lability of karyotype in chromosome evolution.
\end{abstract}

Keywords Basic chromosome number, Chromosome evolution, Dipterocarpaceae, Karyomorphology.

Dipterocarpaceae (Malvales) are a family of 16 genera and 680 species distributed in tropical regions of the Old World, especially in the rain forests of Malesia (Takhtajan 1986, Stevens 2001 onward: http:/www.mo bot.org/MOBOT/research/APweb/). Until recently, the family had been considered comprising three subfamilies Monotoideae, Pakaraimoideae, and Dipterocarpoideae (Maguire and Ashton 1977, Ashton 1982, 2003, Mabberley 2008), but recent molecular studies showed that Pakaraimaea (Pakaraimoideae) is placed near Cistaceae rather than near Dipterocarpoideae (Ducousso et al. 2004, Heckenhauer et al. 2017). Currently, APG IV (The Angiosperm Phylogeny Group 2016) accepts that Dipterocarpaceae comprises two subfamilies alone, i.e., Monotoideae (three genera) and Dipterocarpoideae (13 genera), with Sarcolaenaceae as a sister group.

A larger subfamily Dipterocarpoideae is further subdivided into two tribes Dipterocarpeae (Anisoptera, Cotylelobium, Dipterocarpus, Stemonoporus, Upuna, Vateria, Vateriopsis, and Vatica) and Shoreae (Dryobalanops, Hopea, Neobalanocarpus, Parashorea, and Shorea) (Ashton 1982). As reviewed by Ashton (1982) and Heckenhauer et al. (2017), previous chromosome information on Dipterocarpaceae is restricted to ten genera of Dipterocarpoideae. Four genera Anisoptera, Dipterocarpus, Upuna, and Vatica of tribe Dipterocarpeae have $x=11$; Vateria of tribe Dipterocarpeae has

\footnotetext{
*Corresponding author, e-mail: oginuma_kazuo@yahoo.co.jp DOI: $10.1508 /$ cytologia.85.141
}

$x=10$, and five genera Dryobalanops, Hopea, Neobalanocarpus, Parashorea and Shorea of tribe Shoreae all have $x=7$. Ashton (1982) considered that the basic chromosome number of Dipterocarpeae is (probably) $x=11$, and that of Shoreae (probably) $x=7$. However, molecular phylogenetic analyses revealed that tribe Dipterocarpeae is polyphyletic with Dipterocarpus (Dipterocarpeae) (with $x=11$ ) sister to tribe Shoreae (Kajita et al. 1998, Gamage et al. 2006, Heckenhauer et al. 2017). In the light of such relationships, Kajita et al. (1998) discussed that the basic chromosome number changed from $x=11$ to $x=7$ after Dipterocarpus branched in a common clade with tribe Shoreae. In contrast, Bawa (1998) considered that $x=11$ may have been derived from $x=7$ through alloploidy, because several species in the genera with $x=7$ as the basic number have a somatic chromosome number of $2 n=20,21$ and 22 .

Most of the previous chromosome studies were made by enumerating chromosome numbers alone without micrographs of the chromosomes. Exceptionally, Oginuma et al. (1998a) reported karyomorphology of Anisoptera thurifera Blume using a micrograph, and Heckenhauer et al. (2017) reported karyotypes of six species of four genera Dipterocarpus, Hopea, Shorea, and Vatica. According to Heckenhauer et al. (2017), "karyotypes were similar and symmetrical for all with small metacentric, submetacentric or subtelocentric chromosomes in all analyzed species in Dipterocarpaceae, which makes no identification of individual chromosome pairs difficult." However, we have found a certain diversity in karyo- 
Table 1. Studied taxa and their collection data of Dipterocarpaceae.

\begin{tabular}{ll}
\hline \multicolumn{1}{c}{ Taxon } & \\
\hline Subfamily Monotoideae & Collection \\
Marquesia macroura Gilg & Seeds from Zanbia \\
Subfamily Dipterocarpoideae & \\
Tribe Dipterocarpeae & Cultivated, Singapore Bot. Gard. \\
Anisoptera megistocarpa V. Sl. & Cultivated, Singapore Bot. Gard. \\
Dipterocarpus oblongifolius Blume & Sri lanka, Sinharaja Forest Reserve \\
Vateria indica L. & Cultivated, Singapore Bot. Gard. \\
Vatica pauciflora (Korth.) Bl. & \\
Tribe Shoreae & Cultivated, Singapore Bot. Gard. \\
Dryobalanops aromatica Gaertn. f. & Cultivated, Singapore Bot. Gard. \\
Hopea odorata Roxb. & Cultivated, Singapore Bot. Gard. \\
H. sangal Korth. & Malaysia, Johor Bahru, Panti, Mt. Gunung \\
Neobalanocarpus heimii (Korth.) Ashton & Cultivated, Singapore Bot. Gard. \\
Shorea bracteorata Dyer & Cultivated, Singapore Bot. Gard. \\
S. macroptera Dyer &
\end{tabular}
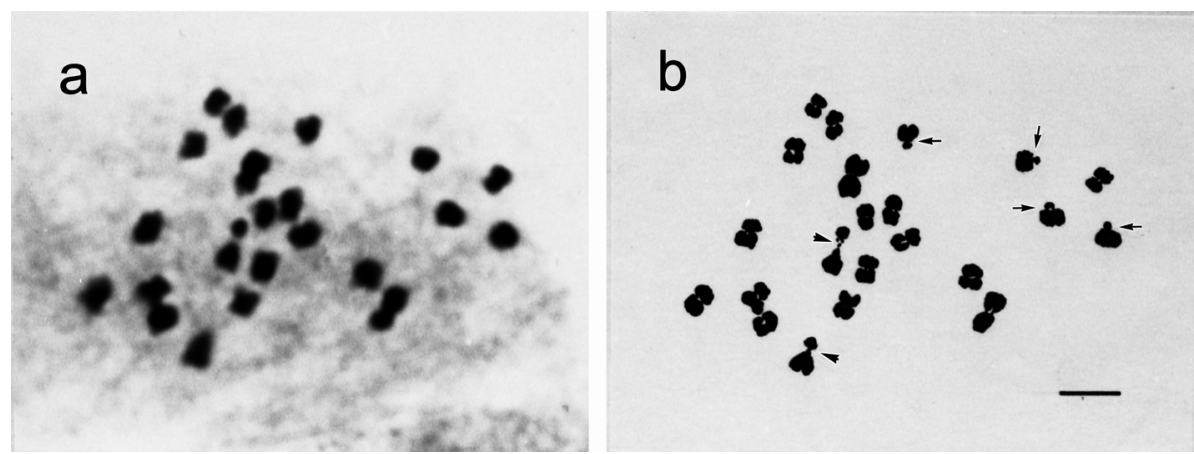

Fig. 1. Somatic chromosomes at metaphase of Marquesia macroura in Monotoideae of Dipterocarpaceae. (b) is a drawing of (a). Arrows indicate chromosomes with centromeres at subterminal position. Arrowheads indicate submetacentric chromosomes with a satellite. Scale bar $=2 \mu \mathrm{m}$.

morphology throughout the family.

In this paper, we provide the first report of the karyotype of subfamily Monotoideae using Marquesia macroura. We further report karyomorphology of four species from four genera of Dipterocarpeae and six species of four genera of Shoreae in subfamily Dipterocarpoideae. Based on the results, we will discuss chromosome evolution and the meaning of karyomorphology diversity in Dipterocarpaceae.

\section{Materials and methods}

The Dipterocarpaceae species investigated are presented in Table 1 along with collection data. Somatic chromosomes were examined using at least three to five cells of young leaves or root tips collected from wildgrowing and cultivated plants. Methods of pretreatment, fixation, and staining for chromosome observations are described elsewhere (leaves: Oginuma et al. 1992, root tips: Oginuma and Nakata 1988). Categories of chromosome morphology on the basis of the position of centromeres followed Levan et al. (1964).
Results

\section{Monotoideae}

Marquesia macroura was studied for the first time. The variation of chromosome length is gradual; the longest chromosome is about $1.6 \mu \mathrm{m}$, and the shortest about $0.9 \mu \mathrm{m}$. Among the 22 chromosomes, 16 have centromeres at median position, two have submedian centromeres, and four have subterminal centromeres. Satellite chromosomes are observed at the proximal region of the short arms of two submedian chromosomes (Fig. 1a, b). The karyotype of the species is $2 n=16 \mathrm{~m}+2 \mathrm{sm}$ (sat) +4 st.

\section{Dipterocarpoideae, Dipterocarpeae}

Anisoptera megistocarpa was studied for the first time. Chromosomes at mitotic metaphase are $2 n=22$. The variation of chromosome length is gradual; the longest chromosome is about $1.6 \mu \mathrm{m}$, and the shortest about $1.1 \mu \mathrm{m}$. Among the 22 chromosomes, 20 have median centromeres, and two have subterminal centromeres. Satellite chromosomes were not observed (Fig. 2a, b). The karyotype of $2 n=20 \mathrm{~m}+2 \mathrm{st}$ resembles that of $A$. thurifera reported earlier (Oginuma et al. 1998a).

Chromosomes at mitotic metaphase of Dipterocarpus oblongifolius are $2 n=22$ as in previous reports (Somego 

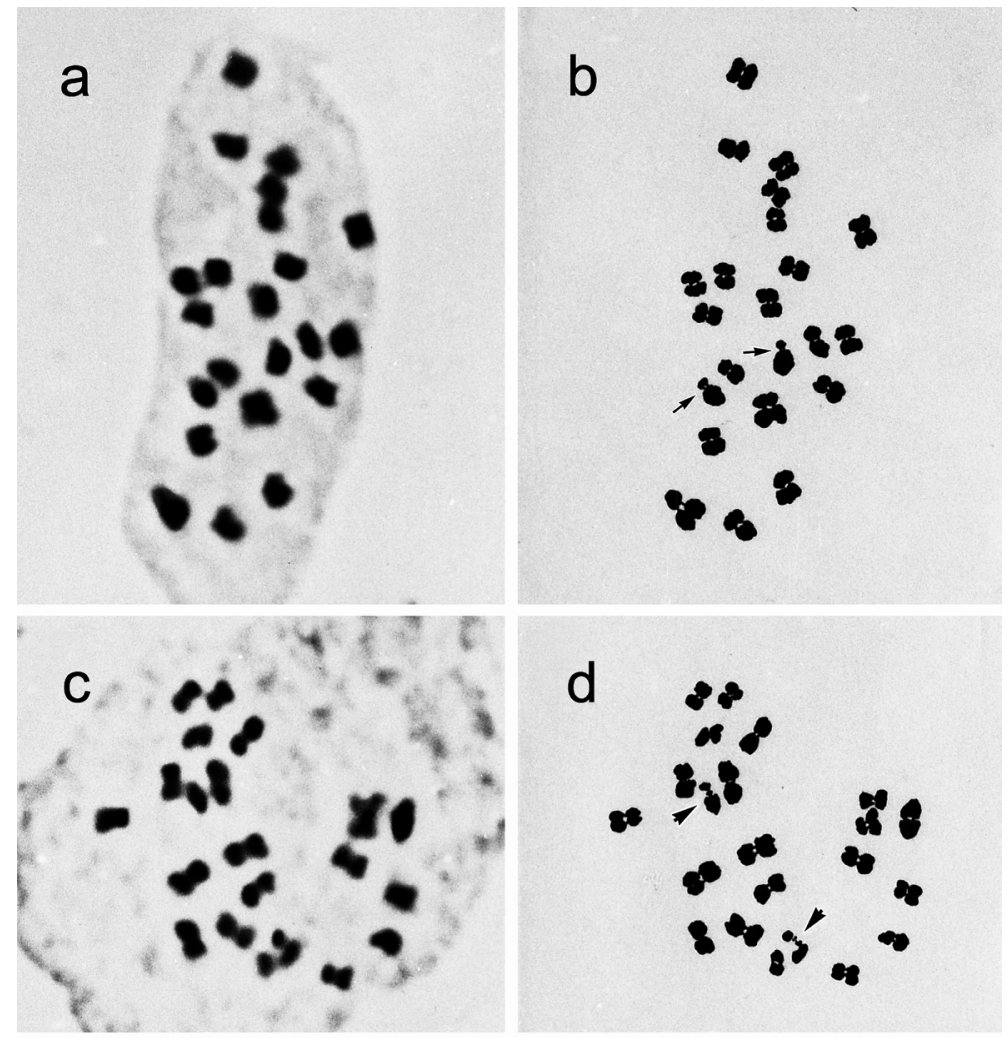

d
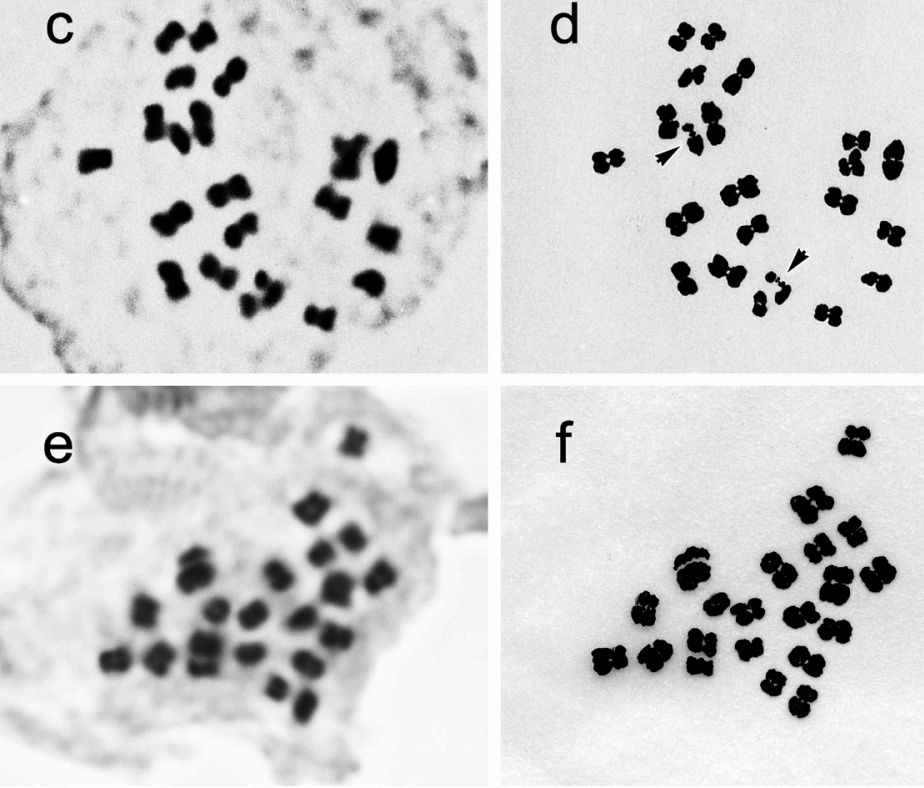

f
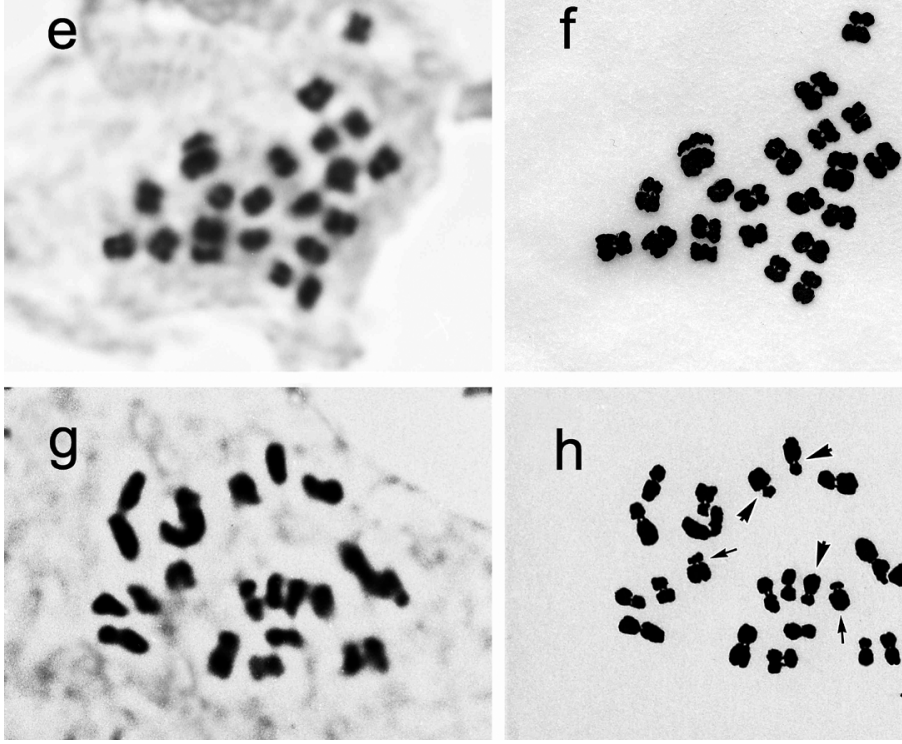

$\mathrm{h}$

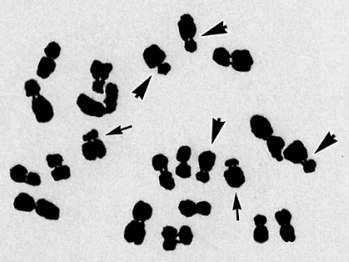

Fig. 2. Somatic chromosomes at metaphase of four genera in Dipterocarpeae of Dipterocarpoideae. (a) and (b): Anisoptera megistocarpa $(2 n=22)$. (c) and (d): Dipterocarpus oblongifolius $(2 n=22)$. (e) and (f): Vateria indica $(2 n=22)$. (g) and (h): Vatica pauciflora $(2 n=22)$. (b), (d), (f) and (h) are respective drawings of (a), (c), (e) and (g). Arrows indicate chromosomes with a centromere at subterminal position. Arrowheads indicate chromosomes with a centromere at submedian position. Arrowheads in (d) indicate submetacentric chromosomes with a satellite. Scale bar $=2 \mu \mathrm{m}$.

1978, Kaur et al. 1986). The variation of chromosome length is gradual: the longest chromosome is about $1.8 \mu \mathrm{m}$, and the shortest about $0.9 \mu \mathrm{m}$. Among 22 chromosomes, 20 have median centromeres, and two have submedian centromeres. Satellite chromosomes are observed in the interstitial region of the short arms in two submedian chromosomes (Fig. 2c, d). The karyotype of the species is $2 n=20 \mathrm{~m}+2 \mathrm{sm}$ (sat).

Chromosomes at mitotic metaphase of Vateria indica are $2 n=22$, a new count for the species in contrast to $n=10$ reported earlier (Mehra 1976). The variation of chromosome length is gradual; the longest chromosome is about $1.4 \mu \mathrm{m}$, and the shortest about $0.9 \mu \mathrm{m}$. All 22 chromosomes have centromeres at median position. Satellite chromosomes are not observed (Fig. 2e, f). The karyotype of the species is $2 n=22 \mathrm{~m}$.

Chromosomes at mitotic metaphase of Vatica pauciflora are $2 n=22$ as reported earlier (Jong and Lethbridge 


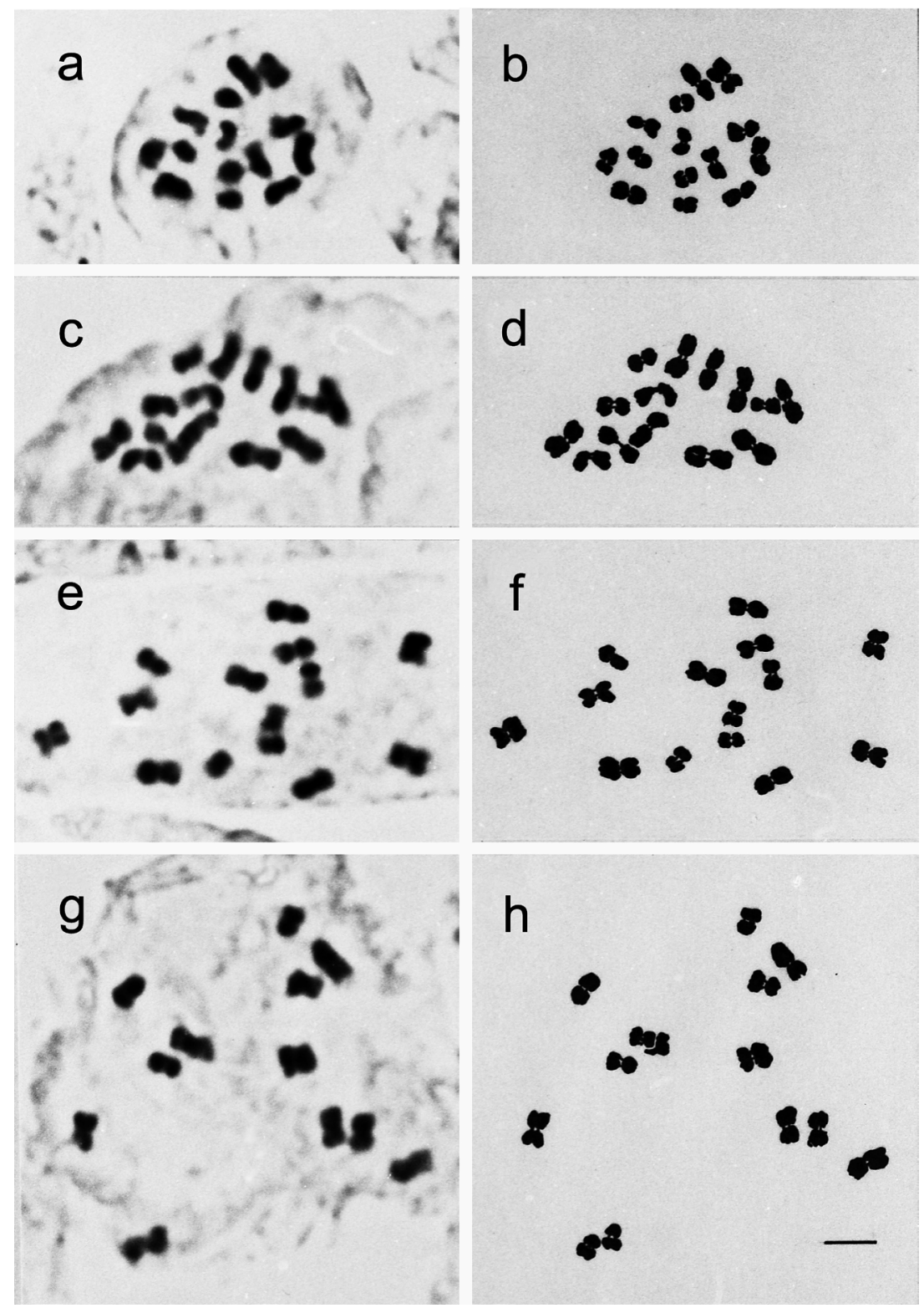

Fig. 3. Somatic chromosomes at metaphase of four genera in Shorea of Dipterocarpoideae. (a) and (b): Dryobalanops aromatica $(2 n=14)$. (c) and (d): Hopea sangal $(2 n=14)$. (e) and (f): Neobalanocarpus heimii $(2 n=14)$. (g) and (h): Shorea bracteorata ( $2 n=14)$. (b), (d), (f) and (h) are respective drawings of (a), (c), (e) and (g). Scale bar $=2 \mu \mathrm{m}$.

1967, Somego 1978). The variation of chromosome length is gradual: the longest is about $2.0 \mu \mathrm{m}$, the shortest about $1.3 \mu \mathrm{m}$. Among 22 chromosomes, 16 have median centromeres, four have submedian centromeres, and two have subterminal centromeres. Satellites are not observed (Fig. 2g, h). The karyotype of the species is $2 n=16 \mathrm{~m}+4 \mathrm{sm}+2 \mathrm{st}$.

\section{Dipterocarpoideae, Shoreae}

Chromosomes at mitotic metaphase of Dryobalanops aromatica are $2 n=14$ as reported earlier (Jong and Lethbridge 1967, Somego 1978). The variation of chromosome length is gradual; the longest chromosome is about $1.6 \mu \mathrm{m}$, and the shortest about $1.1 \mu \mathrm{m}$. All 14 chromosomes have median centromeres. Satellite chromosomes are not observed (Fig. 3a, b). The karyotype of the spe- cies is $2 n=14 \mathrm{~m}$.

Two species, Hopea odorata and $H$. sangal, are studied. Chromosomes at mitotic metaphase of $H$. odorata are $2 n=21$ as reported earlier (Somego 1978, Kaur et al. 1986), and $2 n=14$ for $H$. sangal as reported earlier (Somego 1978). In H. sangal, the chromosome variation is gradual; the longest chromosome is about $1.8 \mu \mathrm{m}$, and the shortest about $1.2 \mu \mathrm{m}$. All 14 chromosomes have median centromeres. Satellite chromosomes were not observed (Fig. 3c, d). The karyotype of $H$. sangal is $2 n=14 \mathrm{~m}$.

Chromosomes of mitotic metaphase of Neobalanocarpus heimii are $2 n=14$ as reported earlier (Somego 1978). The variation of chromosome length is gradual; the longest chromosome is about $1.7 \mu \mathrm{m}$, and the shortest about $1.1 \mu \mathrm{m}$. All 14 chromosomes have median centromeres. 
Table 2. Chromosome data in Dipterocarpaceae.

\begin{tabular}{|c|c|c|c|c|c|}
\hline Subfamily & Tribe & Species & $n$ & $2 n$ & Reference \\
\hline Monotoideae & & Marquesia macroura Gilg & & 22 & Present study \\
\hline \multirow[t]{52}{*}{ Dipterocarpoideae } & Dipterocarpeae & $\begin{array}{l}\text { Anisoptera costata Korth. (as A. cochinchinensis } \\
\text { Pierre ex Laness.) }\end{array}$ & & 20 & Tixier (1953) \\
\hline & & A. laevis Rindl. & & 22 & $\begin{array}{l}\text { Jong and Lethbridge (1967), } \\
\text { Somego (1978) }\end{array}$ \\
\hline & & A. megistocarpa $\mathrm{V} . \mathrm{Sl}$. & & 22 & Present study \\
\hline & & A. scaphula (roxb.) Kurz (as A. glabra Kurz) & & 20 & Tixier (1960) \\
\hline & & & & 22 & Somego (1978) \\
\hline & & A. thurifera Blume & & 22 & Oginuma et al. (1998a) \\
\hline & & Dipterocarpus alatus Roxb. & & 20 & Tixier (1953) \\
\hline & & & 11 & 22 & Roy and Jha (1965) \\
\hline & & D. artocarpifolius Pierre & & 20 & Tixier (1960) \\
\hline & & D. baudii Korth. & & 22 & $\begin{array}{l}\text { Roy and Jha (1965), } \\
\text { Jong and Lethbridge (1967) }\end{array}$ \\
\hline & & D. cornutus & & 22 & Somego (1978) \\
\hline & & $\begin{array}{l}\text { D. costatus Gaertn. f. (as D. artocarpifolius } \\
\text { Pierre ex Laness) }\end{array}$ & & 20 & Tixier (1960) \\
\hline & & D. elongatus Korth. (as D. warburgii Brandis) & & 20 & Pancho (1971) \\
\hline & & D. intricatus Dyer & & 20 & Tixier (1953) \\
\hline & & D. kunsteleri King (as D. speciosus Brandis) & & 20 & Pancho (1971) \\
\hline & & D. oblongifolius Blume & & 22 & $\begin{array}{l}\text { Somego (1978), Kaur et al. (1986), } \\
\text { Present study }\end{array}$ \\
\hline & & D. obtusifolius Teysm. Ex Miq. & & 20 & Tixier (1953) \\
\hline & & D. sarawakensis Sloot. & & 22 & $\begin{array}{l}\text { Roy and Jha (1965), } \\
\text { Jong and Lethbridge (1967) }\end{array}$ \\
\hline & & D. tuberculatus Roxb. & & 20,30 & Tixier (1960) \\
\hline & & D. turbinatus Gaertn. f. & & 20 & Tixier (1960) \\
\hline & & D. zeylanica Thwaites & & 22 & Heckenhauer et al. (2017) \\
\hline & & Upna. borneensis Sym. & & 22 & Somego (1978) \\
\hline & & Vateria indica $\mathrm{L}$. & 10 & & Mehra (1976) \\
\hline & & & & 22 & Present study \\
\hline & & Vatica cinerea Dyer & & 22 & Somego (1978) \\
\hline & & V. endertii Slooten & & 22 & Heckenhauer et al. (2017) \\
\hline & & V. odorata (Griff.) Sym. (as $V$. grandiflora Dyer) & 11 & & Roy and Jha (1965) \\
\hline & & & & 22 & Roy and Jha (1965), Somego (1978) \\
\hline & & $V$. papana Dyer & & 22 & Jong and Lethbridge (1967) \\
\hline & & V. pauciflora (Korth.) Ashton (as $V$. walichii Dyer) & 11 & & Jong and Lethbridge (1967) \\
\hline & & & & 22 & Present study \\
\hline & & V. stapfiana (King) V. Sl. & & 22 & Jong and Lethbridge (1967) \\
\hline & Shoreae & Dryobalanops aromatica Gaertn. f. & & 14 & $\begin{array}{l}\text { Jong and Lethbridge (1967), } \\
\text { Somego (1978), Present study }\end{array}$ \\
\hline & & D. oblongifolia Dyer & & 14 & $\begin{array}{l}\text { Jong and Lethbridge (1967), } \\
\text { Somego (1978) }\end{array}$ \\
\hline & & Hopea beccariana Burck & & $20,21,22$ & Somego (1978) \\
\hline & & $\begin{array}{l}\text { H. glabra W. \& A. (as H. wightiana Wall ex W. } \\
\text { \& A.) }\end{array}$ & & 14 & Jong and Lethbridge (1967) \\
\hline & & H. jucunda Thwaites & & 21 & Heckenhauer et al. (2017) \\
\hline & & H. latifolia Sym. (as H. beccariana Burck) & & 21 & Jong and Kaur (1979) \\
\hline & & H. nervosa King & & 14 & Somego (1978), Kaur et al. (1986) \\
\hline & & H. nutans Ridl. & 14 & & Jong and Lethbridge (1967) \\
\hline & & & & 28 & Somego (1978) \\
\hline & & H. odorata Roxb. & 7 & & Roy and Jha (1965), Sarkar et al. (1982) \\
\hline & & & & 14 & Roy and Jha (1965) \\
\hline & & & & 20 & Tixier (1953) \\
\hline & & & & $20,21,22$ & Somego (1978), Kaur et al. (1986) \\
\hline & & & & 21 & Present study \\
\hline & & H. pubescens Ridl. & c.7 & & Jong and Lethbridge (1967) \\
\hline & & H. sangal Korth. & & 14 & Somego (1978), Present study \\
\hline & & H. subalata Sym. & & 21 & $\begin{array}{l}\text { Jong and Kaur (1979), } \\
\text { Kaur et al. (1986) }\end{array}$ \\
\hline & & & & $20,21,22$ & Somego (1978) \\
\hline & & Neobalanocarpus heimii (Korth.) Ashton & & 14 & $\begin{array}{l}\text { Jong and Lethbridge (1967), } \\
\text { Somego (1978), } \\
\text { Present study }\end{array}$ \\
\hline & & Parashorea densiflora Sym. & & 14 & Somego (1978) \\
\hline
\end{tabular}


Table 2. Continued.

\begin{tabular}{|c|c|c|c|c|c|}
\hline Subfamily & Tribe & Species & $n$ & $2 n$ & Reference \\
\hline \multirow[t]{45}{*}{ Dipterocarpoideae } & Shoreae & Shorea acuminata Dyer & & 14 & Somego (1978), Kaur et al. (1986) \\
\hline & & S. agami Ashton & & 14 & Kaur et al. (1986) \\
\hline & & S. argentifolia Sym. & & 14 & Somego (1978), Kaur et al. (1986) \\
\hline & & S. assamica Dyer & & 14 & Somego (1978), Present study \\
\hline & & S. bracteorata Dyer & & 14 & Somego (1978) \\
\hline & & S. contorta Vidal & & 14 & Kaur et al. (1986) \\
\hline & & S. curtisii Dyer ex King & & 14 & $\begin{array}{l}\text { Jong and Lethbridge (1967), } \\
\text { Somego (1978) }\end{array}$ \\
\hline & & S. gardneri (Thw.) Ashton & & 14 & Jong and Kaur (1979) \\
\hline & & S. glauca King & & 14 & Somego (1978) \\
\hline & & S. guiso (Blco.) Bl. & & 14 & Somego (1978) \\
\hline & & S. hypochroa Hance & & 14 & Somego (1978) \\
\hline & & S. lepidota Miq. & & 14 & Kaur et al. (1986) \\
\hline & & S. leprosula Miq. & & 14 & $\begin{array}{l}\text { Jong and Lethbridge (1967), } \\
\text { Somego (1978) }\end{array}$ \\
\hline & & S. macrophylla (de Vr.) Ashton & & 14 & Jong and Kaur (1979), Kaur et al. (1986) \\
\hline & & S. macroptera Dyer & & 14 & $\begin{array}{l}\text { Somego (1978), Kaur et al. (1986), } \\
\text { Present study }\end{array}$ \\
\hline & & S. maxwellana King & & 14 & Somego (1978) \\
\hline & & S. mecistopteryx Ridl. & & 14 & Somego (1978) \\
\hline & & S. megistophylla Ashton & & 14 & Heckenhauer et al. (2017) \\
\hline & & S. multiflora (Burck) Sym. & & 14 & Somego (1978), Kaur et al. (1986) \\
\hline & & S. oblongifolia Thwaites & & 14 & Heckenhauer et al. (2017) \\
\hline & & S. obtusa Wall & & 20 & Tixier (1960) \\
\hline & & S. ovalis (Korth.) B1. & 14 & & Jong and Lethbridge (1967) \\
\hline & & & & 21 & Jong and Kaur (1979) \\
\hline & & & & 28 & $\begin{array}{l}\text { Jong and Lethbridge (1967), } \\
\text { Somego (1978), Kaur et al. (1986) }\end{array}$ \\
\hline & & S. palembanica Miq. & & 14 & Somego (1978) \\
\hline & & S. parvifolia Dyer & & 14 & Somego (1978) \\
\hline & & S. pauciflora King & & 14 & $\begin{array}{l}\text { Jong and Lethbridge (1967), } \\
\text { Somego (1978), Kaur et al. (1986) }\end{array}$ \\
\hline & & S. pinanga Scheff. (as $S$. compress Burck) & & 12 & Tixier (1960) \\
\hline & & & & 14 & $\begin{array}{l}\text { Nanda (1962), Roy and Jha (1965), } \\
\text { Kaur et al. (1986) }\end{array}$ \\
\hline & & & & 21 & Jong and Kaur (1979) \\
\hline & & S. platyclados Sloonten ex Foxw. & & 14 & Somego (1978), Kaur et al. (1986) \\
\hline & & S. resinosa Foxw. & & 14 & Jong and Kaur (1979) \\
\hline & & & & 21 & Kaur et al. (1986) \\
\hline & & S. robustus Gaertn. f. & 7 & & $\begin{array}{l}\text { Roy and Jha (1965), Mehra (1976), } \\
\text { Mehra and Sareen }(1969,1973), \\
\text { Singhal and Gill (1984) }\end{array}$ \\
\hline & & & & 14 & Roy and Jha (1965), Pal et al. (1993) \\
\hline & & S. roxburghii G.Don & & 14 & Heckenhauer et al. (2017) \\
\hline & & $\begin{array}{l}\text { S. siamensis Miq. (as Pentacme siamensis (Miq.) } \\
\text { DC.) }\end{array}$ & & 12 & Tixier (1953) \\
\hline & & S. singkang (Miq.) Burck & 7 & & Jong and Lethbridge (1967) \\
\hline & & S. smithiana Sym. & 7 & & Jong and Lethbridge (1967) \\
\hline & & S. spendida (de Vries) Ashton & & 14 & Kaur et al. (1986) \\
\hline & & $\begin{array}{l}\text { S. splendida (de Vr.) Ashton (as S. martiniana } \\
\text { Scheff.) }\end{array}$ & & 14 & Somego (1978) \\
\hline & & S. stenoptera Burck & & 14 & Jong and Kaur (1979), Kaur et al. (1986) \\
\hline & & S. sumatrana (Sl. ex Thor.) Sym. & 7 & & Jong and Lethbridge (1967) \\
\hline & & S. talura Roxb. & 7 & 14 & Roy and Jha (1965) \\
\hline & & S. trapezifolia Ashton & & 14 & Jong and Kaur (1979), Kaur et al. (1986) \\
\hline
\end{tabular}

Satellite chromosomes are not observed (Fig. 3e, f). The karyotype of the species is $2 n=14 \mathrm{~m}$.

Two species, Shorea bracteolata, and $S$. macroptera, were studied. Chromosomes at mitotic metaphase of S. bracteolata are $2 n=14$ as reported earlier (Somego 1978), and $2 n=14$ of $S$. macroptera as reported earlier (Somego 1978, Kaur et al. 1986). In S. bracteolata, the variation of chromosome length is gradual; the longest chromosome is about $1.8 \mu \mathrm{m}$, and the shortest about $1.1 \mu \mathrm{m}$. All 14 chromosomes have median centromeres. Satellite chromosomes are not observed (Fig. 3g, h). The karyotype of the species is $2 n=14 \mathrm{~m}$. The karyotype of $S$. macroptera resembled that of $S$. baracteolata, and is $2 n=14 \mathrm{~m}$. 


\section{Discussion}

By adding the results of the present study, we have updated chromosome information of Dipterocarpaceae (Table 2). Important information we have added include $2 n=22$ of Marquesia (Monotoideae) as well as of Vateria (Dipterocarpoideae, Dipterocarpeae). By means of our study, we could show that, like Dipterocarpoideae, another subfamily Monotoideae also have $x=11$. As for $\mathrm{Va}$ teria, $n=10$ of $V$. indica was the only chromosome count (Mehra 1976), although Ashton (1982) described "The diploid numbers of one species of Stenmonoporus, and two of Vateria, all $2 n=22$ " (see also Heckenhauer et al. 2017). In the present study, we explicitly showed using micrograph that Vateria indica has $2 n=22$. Therefore, the genera (Anisoptera, Dipterocarpus, Upuna, Vateria, and Vatica) investigated for chromosome counts of tribe Dipterocarpeae all have $x=11$. A few species of tribe Dipterocarpeae are reported by the same authors (Tixier 1953, 1960, Pancho 1971) to have $2 n=20$ (Table 2). They now need reconfirmation.

\section{Evolution of karyotypes in Dipterocarpaceae}

As stated in the Introduction, two contrasting hypotheses have existed about chromosome evolution in Dipterocarpaceae, one from $x=7$ to $x=11$ (Bawa 1998), and the other from $x=11$ to $x=7$ (Kajita et al. 1998). As in Kajita et al. (1998), almost all of molecular phylogenetic studies have indicated that Dipterocarpus $(x=11)$ forms a common clade with tribe Shoreae (with $x=7$ ) rather than with the rest of tribe Dipterocarpeae (with $x=11$ ) (Tsumura et al. 1996, Ducousso et al. 2004, Gamage et al. 2006, Heckenhaur et al. 2017). Our study showed that Marquesia macroura (Monotoideae) has $2 n=22$, a fact suggesting that another subfamily Monotoideae likely has $x=11$ as in Dipterocarpeae. Also, Sarcolaenaceae, which are considered sister to Dipterocarpaceae (Ducousso et al. 2004, Heckenhauer et al. 2017), also have $x=11$ because both Leptolaena and Sarcolaena were reported to have $2 n=22$ (Goldblatt and Dorr 1986). A distribution of $x=7$ and 11 on the phylogenetic tree shows that $x=11$ is plesiomorphic with $x=7$ apomorphic in Dipterocarpaceae, and that the basic chromosome

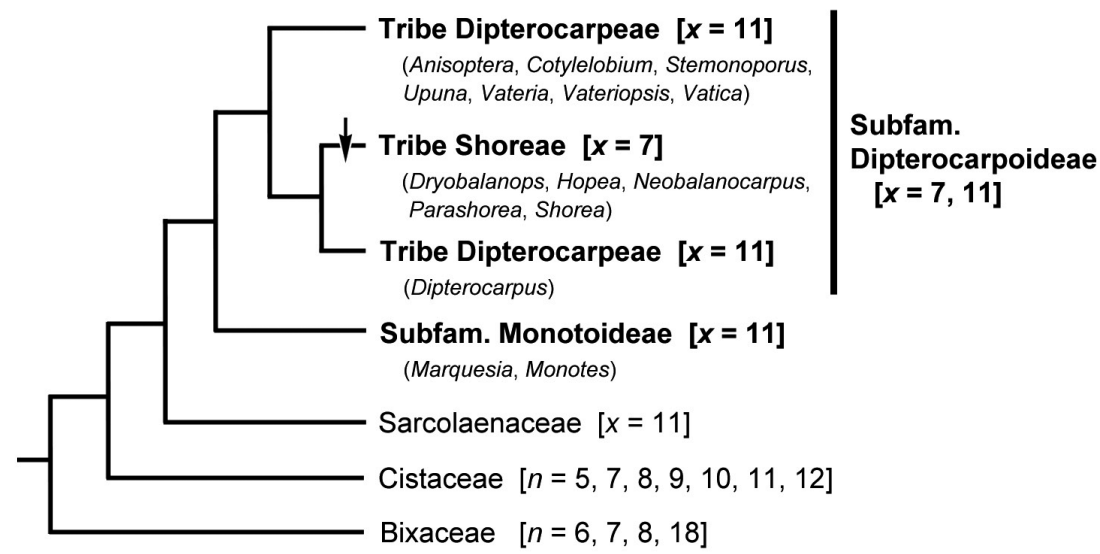

Fig. 4. Evolution of basic chromosome numbers in Dipterocarpaceae. Phylogenetic tree is modified from Heckenhauer et al. (2017). An arrow indicates an evolution of $x=7$ from $x=11$. Chromosome data of Bixaceae and Cistaceae are from Orunduff (1967, 1968), Moore (1973, 1974, 1977), Fedorov (1974), Goldblatt (1981, 1984, 1985, 1988), and Goldblatt and Johnson (1990, 1991, 1994, 1996, 1998, 2000, 2003, 2006, 2010).

Table 3. A summary of karyoype of Dipterocarpaceae.

\begin{tabular}{|c|c|c|c|c|}
\hline \multirow{2}{*}{ Subfamily/Tribe/Genus } & \multirow{2}{*}{$2 n(x)$} & \multicolumn{3}{|c|}{ Chromosome morphology ${ }^{1)}$} \\
\hline & & $\mathrm{m}$ & $\mathrm{sm}$ & st \\
\hline \multicolumn{5}{|l|}{ Monotoideae } \\
\hline Marquesia & $22(11)$ & $16(73 \%)$ & $2(9 \%)^{2)}$ & $4(18 \%)$ \\
\hline \multicolumn{5}{|l|}{ Dipterocarpoideae } \\
\hline \multicolumn{5}{|l|}{ Dipterocarpeae } \\
\hline Anisoptera & $22(11)$ & $20(91 \%)$ & $0(0 \%)$ & $2(9 \%)$ \\
\hline Dipterocarpus & $22(11)$ & $20(91 \%)$ & $2(9 \%)^{2)}$ & $0(0 \%)$ \\
\hline Vateria & $22(11)$ & $22(100 \%)$ & $0(0 \%)$ & $0(0 \%)$ \\
\hline Vatica & $22(11)$ & $16(73 \%)$ & $4(18 \%)$ & $2(9 \%)$ \\
\hline \multicolumn{5}{|l|}{ Shoreae } \\
\hline Dryobalanops & $14(7)$ & $14(100 \%)$ & $0(0 \%)$ & $0(0 \%)$ \\
\hline Hopea & $14(7)$ & $14(100 \%)$ & $0(0 \%)$ & $0(0 \%)$ \\
\hline Neobalanocarpus & $14(7)$ & $14(100 \%)$ & $0(0 \%)$ & $0(0 \%)$ \\
\hline Shorea & $14(7)$ & $14(100 \%)$ & $0(0 \%)$ & $0(0 \%)$ \\
\hline
\end{tabular}

1) Abbreviations; $\mathrm{m}$, chromosomes with a centromere at median position; sm, chromosomes with a centromere at submedian position; st, chromosomes with a centromere at subterminal positon. ${ }^{2)}$ Chromosomes with a satellite. 
number evolved from $x=11$ to $x=7$ in tribe Shoreae within the family (Fig. 4).

Evolution toward a markedly discontinuous basic chromosome number as in Dipterocarpaceae is not rare. For example, in Hamamelidaceae $x=8$ and $x=12$ are known (Oginuma and Tobe 1991); likewise, $x=8, x=11$, $x=14$ are known in Betulaceae (Oginuma et al. 1998b), and $x=7, x=9, x=12$ in Stemonoaceae (Oginuma et al. 2001).

In the present study, we further showed that diversity exists in karyotype throughout Dipterocarpaceae (for a summary see Table 3). The karyotype of tribe Shoreae $(2 n=14)$ is very uniform, consistently comprising seven pairs of chromosomes with a centromere at median position. In contrast, the karyotypes of tribe Dipterocarpeae $(2 n=22)$ are diverse in the frequency of chromosomes with a centromere at median, submedian, and subterminal position. Except in Vateria, one pair of chromosomes has a centromere at the submedian and/or subterminal position in tribe Dipterocarpeae, i.e., Anisoptera, Dipterocarpus, and Vatica. This is also the case of Marquesia, in which one pair of chromosome has a centromere at submedian position, and another two pairs have a centromere at subterminal position. As far as based on data available from nine genera of Dipterocarpaeae, lability of karyotype is plesiomorphic in the family. The uniform karyotype of $x=7$ as in tribe Shoreae may have been derived from $x=11$ showing a labile karyotype by chromosome fusion.

\section{References}

Ashton, P. S. 1982. Dipterocarpaceae. In: Van Steenis C. G. G. J. (ed.). Flora Malesiana. Series I, Spermatophyta. Flowering Plants, vol. 9, part 2, Martinus Nijhoff Pub., Leiden. pp. 237-552.

Ashton, P. S. 2003. Dipterocarpaceae. In: Kubitzki, K. and Bayer, C. (eds.). The Families and Genera of Vascular. Plants. Vol. 5. Flowering Plants Dicotyledons. Malvales, Caparales, Non-betalain Caryophyllales. Springer, Berlin. pp. 182-197.

Bawa, K. S. 1998. Conservation of Genetic Resources in the Dipterocarpaceae. In: Appanah, S. and Turnbull, J. M. (eds.). A Review of Dipterocarps, Taxonomy, Ecology and Silviculture. Center for Forest Research Institute, Bogor. pp. 45-56.

Ducousso, M., Béna, G., Bourgeois, C., Buyck, B., Eyssartier, G., Vincelette, M., Rabevohitra, R., Randrihasipara, L., Dreyfus, B. and Prin, Y. 2004. The last common ancestor of Sarcolaenaceae and Asian dipterocarp trees was ectomycorrhizal before the India-Madagascar separation, about 88 million years ago. Mol. Ecol. 13: 231-236.

Fedorov, A. A. 1974. Chromosome Numbers of Flowering Plants. Otto Koeltz, Koeningstein.

Gamage, D. T., de Silva, M. P., Inomata, N., Yamazaki, T. and Szmidt, A. E. 2006. Comprehensive molecular phylogeny of the sub-family Dipterocarpoideae (Dipterocarpaceae) based on chloroplast DNA sequences. Genes Genet. Syst. 81: 1-12.

Goldblatt, P. 1981. Index to Plant Chromosome Numbers 1975-1978. Monogr. Syst. Bot. Mo. Bot. Gard. 5: 1-553.

Goldblatt, P. 1984. Index to Plant Chromosome Numbers 1979-1981. Monogr. Syst. Bot. Mo. Bot. Gard. 8: 1-427.

Goldblatt, P. 1985. Index to Plant Chromosome Numbers 1982-1983.
Monogr. Syst. Bot. Mo. Bot. Gard. 13: 1-224.

Goldblatt, P. 1988. Index to Plant Chromosome Numbers 1984-1985. Monogr. Syst. Bot. Mo. Bot. Gard. 23: 1-264.

Goldblatt, P. and Dorr, L. J. 1986. Chromosome number in Sarcolaenaceae. Ann. Mo. Bot. Gard. 73: 828-829.

Goldblatt, P. and Johnson, D. E. 1990. Index to Plant Chromosome Numbers 1986-1987. Monogr. Syst. Bot. Mo. Bot. Gard. 30: $1-243$.

Goldblatt, P. and Johnson, D. E. 1991. Index to Plant Chromosome Numbers 1988-1989. Monogr. Syst. Bot. Mo. Bot. Gard. 40: $1-238$.

Goldblatt, P. and Johnson, D. E. 1994. Index to Plant Chromosome Numbers 1990-1991. Monogr. Syst. Bot. Mo. Bot. Gard. 51: $1-267$.

Goldblatt, P. and Johnson, D. E. 1996. Index to Plant Chromosome Numbers 1992-1993. Monogr. Syst. Bot. Mo. Bot. Gard. 51: $1-267$.

Goldblatt, P. and Johnson, D. E. 1998. Index to Plant Chromosome Numbers 1994-1995. Monogr. Syst. Bot. Mo. Bot. Gard. 58: $1-276$.

Goldblatt, P. and Johnson, D. E. 2000. Index to Plant Chromosome Numbers 1996-1997. Monogr. Syst. Bot. Mo. Bot. Gard. 69: $1-208$.

Goldblatt, P. and Johnson, D. E. 2003. Index to Plant Chromosome Numbers 1998-2000. Monogr. Syst. Bot. Mo. Bot. Gard. 81: $1-188$.

Goldblatt, P. and Johnson, D. E. 2006. Index to Plant Chromosome Numbers 2001-2003. Monogr. Syst. Bot. Mo. Bot. Gard. 94: $1-297$.

Goldblatt, P. and Johnson, D. E. 2010. Index to Plant Chromosome Numbers 2004-2006. A. R. G. Gartner Verlag, Ruggell.

Heckenhauer, J., Samuel, R., Ashton, P. S., Turner, B., Barfuss, M. H. J., Jang, T.-S., Temsch, E. M., Mccann, J., Salim, K. A., Attanayake, A. M. A. S. and Chase, M. W. 2017. Phylogenetic analyses of plastid DNA suggest a different interpretation of morphological evolution than those used as the basis for previous classifications of Dipterocarpaceae (Malvales). Bot. J. Linn. Soc. 185: $1-26$.

Jong, K. and Lethbridge, A. 1967. Cytological studies in the Dipterocarpaceae, I. Chromosome numbers of certain Malaysian genera. Notes Roy. Bot. Gard. Edinb. 27: 175-184.

Jong, K. and Kaur, A. 1979. A cytotaxonomic view of Dipterocarpaceae with some comments on polyploidy and apomixes. Mem. Mus. Natl. Hist. Nat., Ser. B. Bot. 26: 41-49.

Kajita, T., Kamiya, K., Nakamura, K., Tachida, H., Wickneswari, R., Tsumura, Y., Yoshimura, H. and Yamazaki, T. 1998. Molecular phylogeny of Dipterocarpacae in Southeast Asia based on nucleotide sequences of $m a t \mathrm{~K}, \operatorname{trn} \mathrm{L}$ intron, and $\operatorname{trn} \mathrm{L}-\operatorname{trn\mathrm {F}}$ intergenic spacer region in chloroplast DAN. Mol. Phylogenet. Evol. 10: 202-209.

Kaur, A., Johb, K., Sands, V. E. and Soepadmo, E. 1986. Cytoembryology of some Malaysian dipterocarps, with some evidence of apomixis. Bot. J. Linn. Soc. 92: 75-88.

Levan, A., Fredga, K. and Sandberg, A. A. 1964. Nomenclature for centromeric position of chromosomes. Hereditas 52: 201-220.

Mabberley, D. J. 2008. Mabberley's Plant-Book. A Portable Dictionary of Plants, Their Classification and Use. 3rd edn. Cambridge University Press, New York.

Maguire, B. P. C. and Ashton, P. S. 1977. Pakaraimoideae, Dipterocarpaceae of the Western Hemisphere II. Systematic, geographic and phyletic considerations. Taxon 26: 341-368.

Mehra, P. N. 1976. Cytology of Himalayan Hardwoods. Sree Saraswaty Press, Calcutta.

Mehra, P. N. and Sareen, T. S. 1969. In: Löve, V. (ed.). IOPB Chromosome Number Report XXII. Taxon 18: 433-442.

Mehra, P. N. and Sareen, T. S. 1973. Cytology of some Himalayan 
trees. Silvae Genet. 22: 66-70.

Moore, R. J. 1973. Index to Plant Chromosome Numbers 1967-1971. Oosthoek's Uigeversmaatsschappiji B. V., Utrecht.

Moore, R. J. 1974. Index to Plant Chromosome Numbers for 1972. Oosthoek's Uigeversmaatsschappiji B. V., Utrecht.

Moore, R. J. 1977. Index to Plant Chromosome Numbers for 19731974. Bohn, Scheltema and Holkema, Utrecht.

Nanda, P. C. 1962. Chromosome number of some trees and shrubs. J. Indian Bot. Soc. 41: 271-277.

Oginuma, K. and Nakata, M. 1988. Cytological studies on phanerogams in Southern Peru, I. Karyotype of Acaena ovalifolia. Bull. Natl. Sci. Mus. Tokyo. Ser. B 14: 53-56.

Oginuma, K. and Tobe, H. 1991. Karyomorphology and evolution in some Hamamelidaceae and Platanaceae (Hamemelididae; Hamamelidales). Bot. Mag. Tokyo 104: 115-135.

Oginuma, K., Ibarra-Manriquez and Tobe, H. 1992. Chromosomes of Tuxtla pittieri (Asteraceae; Heliantheae). Acta Phytotax. Geobot. 43: $135-137$.

Oginuma, K., Kiaptranis, R., Damas, K. and Tobe, H. 1998a. A cytological study of some plants from Papua New Guinea. Acta Phytotax. Geobot. 49: 105-114.

Oginuma, K., Kato, H. and Tobe, H. 1998b. Chromosome base number of Corylus (Betulaceae): Correction, and evolution. Acta Phytotax. Geobot. 49: 99-104.

Oginuma, K., Horiuchi, K. and Fukuhara, T. 2001. Karyomorphology of two genera in Stemonaceae. Acta Phytotax. Geobot. 52: $57-63$.

Ornduff, R. 1967. Index to Plant Chromosome Numbers for 1965. The International Bureau for Plant Taxonomy and Nomenclature, Utrecht.
Ornduff, R. 1968. Index to Plant Chromosome Numbers for 1966. The International Bureau for Plant Taxonomy and Nomenclature, Utrecht.

Pal, J. K., Mandal, S. and Bhattacharya, G. N. 1993. Cytopalynological studies in Shorea robusta Gaertn f. Sci. Cult. 59: 55-57.

Pancho, J. V. 1971. In: Löve, V. (ed.). IOPB chromosome number reports XXXIV. Taxon 20: 785-787.

Roy, R. P. and Jha, P. R. 1965. Cytological studies in Dipterocarpaceae. I. J. Indian Bot. Soc. 44: 387-397.

Sarkar, A. K., Datta, N., Chatterjee, U. and Hazra, D. 1982. In: Löve, V. (ed.). IOPB chromosome number reports LXXVI. Taxon 32: 576-579.

Singhal, V. K. and Gill, B. S. 1984. SOCGI plant chromosome number reports-II. J. Cytol. Genet. 19: 115-117.

Somego, M. 1978. Cytogenetical study of the Dipterocarpaceae. Malays. Forester 41: 358-366.

Takhtajan, A. 1986. Floristic Regions of the World. University of California Press, Berkeley.

The Angiosperm Phylogeny Group 2016. An update of the Angiosperm Phylogeny Group classification for the orders and families of flowering plants: APG IV. Bot. J. Linn. Soc. 181: 1-20.

Tixier, P. 1953. Donnees cytologiques sur quelques Guttiferales du Viet-Nam. Rev. Cytol. Biol. Veg. 14: 1-12.

Tixier, P. 1960. Donnees cytologiques sur quelques Guttiferales du recoltees au Raos. Rev. Cytol. Biol. Veg. 22: 65-70.

Tsumura, Y., Kawahara, T., Wickneswari, R. and Yoshimura, K. 1996. Molecular phylogeny of Dipterocarpaceae in Southeast Asia using RFLP of PCR-amplified chloroplast genes. Theor. Appl. Genet. 93: 22-29. 